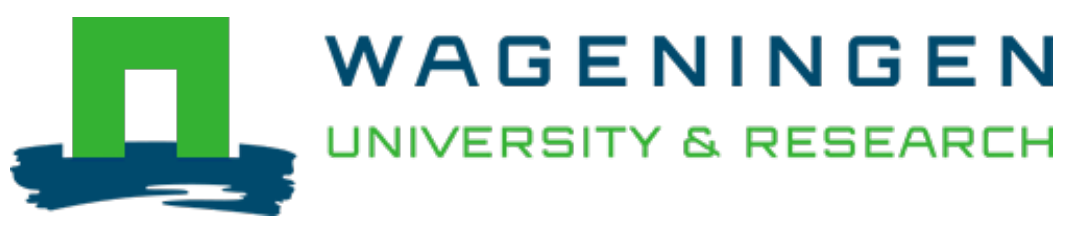

\author{
Rich nutrition from the poorest - Cereal fermentations in Africa and Asia \\ Food Microbiology \\ Nout, M.J.R. \\ https://doi.org/10.1016/j.fm.2009.07.002
}

This publication is made publicly available in the institutional repository of Wageningen University and Research, under the terms of article $25 \mathrm{fa}$ of the Dutch Copyright Act, also known as the Amendment Taverne. This has been done with explicit consent by the author.

Article $25 \mathrm{fa}$ states that the author of a short scientific work funded either wholly or partially by Dutch public funds is entitled to make that work publicly available for no consideration following a reasonable period of time after the work was first published, provided that clear reference is made to the source of the first publication of the work.

This publication is distributed under The Association of Universities in the Netherlands (VSNU) 'Article $25 \mathrm{fa}$ implementation' project. In this project research outputs of researchers employed by Dutch Universities that comply with the legal requirements of Article $25 \mathrm{fa}$ of the Dutch Copyright Act are distributed online and free of cost or other barriers in institutional repositories. Research outputs are distributed six months after their first online publication in the original published version and with proper attribution to the source of the original publication.

You are permitted to download and use the publication for personal purposes. All rights remain with the author(s) and / or copyright owner(s) of this work. Any use of the publication or parts of it other than authorised under article $25 \mathrm{fa}$ of the Dutch Copyright act is prohibited. Wageningen University \& Research and the author(s) of this publication shall not be held responsible or liable for any damages resulting from your (re)use of this publication.

For questions regarding the public availability of this publication please contact openscience.library@wur.nl 


\title{
Rich nutrition from the poorest - Cereal fermentations in Africa and Asia
}

\author{
M.J.Rob Nout* \\ Laboratory of Food Microbiology, Wageningen University, Bomenweg 2, 6703 HD Wageningen, The Netherlands
}

\section{A R T I C L E I N F}

\section{Article history:}

Received 28 April 2009

Received in revised form

3 July 2009

Accepted 8 July 2009

Available online 15 July 2009

\section{Keywords:}

Maize

Sorghum

Millet

Rice

Lactic acid bacteria

Yeasts

Filamentous fungi

Mixed fermentation

Co-fermentation

Micronutrients

Digestibility

Mineral fortification

Phytic acid

NaFeEDTA

\begin{abstract}
A B S T R A C T
Cereal fermentations in Africa and Asia involve mainly the processing of maize, rice, sorghum and the millets. Lactic acid bacteria (Lactobacillus, Pediococcus), Enterobacter spp., yeasts (Candida, Debaryomyces, Endomycopsis, Hansenula, Pichia, Saccharomyces and Trichosporon spp.) and filamentous fungi (Amylomyces, Aspergillus, Mucor, and Rhizopus spp.) contribute to desirable modifications of taste, flavour, acidity, digestibility, and texture in non-alcoholic beverages (e.g., uji, and ben-saalga), porridges (e.g., mawè) and cooked gels (e.g., kenkey, idli, and mifen). In addition, alcoholic beverages (beers such as tchoukoutou and jnard; and spirits e.g. jiu) are obtained using malt, or using amylolytic mixed microbial starter cultures as generators of fermentable substrates. Wet processing, marketing of multi-purpose intermediate products, co-fermentation for texture and nutrition, and mixed culture fermentations as practiced in indigenous fermentation processes are of interest for industrial innovation and for better control of natural mixed culture fermentation systems. On the other hand, the nutritional properties of traditional cereal fermented products can be enhanced by increasing their nutrient and energy density, as well as by increasing their mineral status by combining mineral fortification and dephytinization.
\end{abstract}

(c) 2009 Elsevier Ltd. All rights reserved.

\section{Introduction}

"Rich nutrition from the poorest" is a title that could be interpreted in different ways.

Do we aim at obtaining an adequate nutrition from the poorest of ingredients? Cereals offer several challenges from a nutrition point of view, especially the swelling of their starch upon cooking, the limited quantity and amino acid profile of their protein fraction, and the limited bioavailability of their mineral content due to relatively low mineral levels and the presence of phytic acid and other antinutritional factors that reduce their bioavailability to 5-15\%.

Or are we interested how low-income populations manage to obtain a "rich" nutrition from cereals? Fermented cereal products play an important role in African and Asian dietary culture because of their attractive flavour and texture.

\footnotetext{
* Tel.: +31317482834; fax: +31317484978.

E-mail address: rob.nout@wur.nl

URL: http://www.fhm.wur.nl
}

How are these properties achieved, and offer traditional technologies opportunities for Western food technology? Some of these aspects will be discussed, while referring to the increasing scientific evidence which accumulates about tropical fermented cereal foods.

\section{Cereal fermentations in Africa and Asia}

Cereals are used world-wide as staple foods. A large proportion of the world cereals production is processed by fermentation prior to consumption. The enhancement of attractive flavour and texture, and the improved shelf-life and digestibility as a result of fermentation are important reasons for this. In Africa and Asia, cereals of major importance are maize (Zea mays), sorghum (Sorghum vulgare), rice (Oryza sativa), and several minor grains such as the millets, especially pearl millet (Pennisetum glaucum) and finger millet (Eleusine coracana).

A wide range of cereal-derived consumer products is known, often with specific local differences in composition and method of preparation. A few principal categories of African and Asian cereal products could be distinguished, i.e. (semi)-solid cooked doughs and porridges, and liquid beverages. The latter can be differentiated 
into non-alcoholic gruels, beers, wines and spirits. Table 1 presents a limited overview of these categories, showing the food items that will be discussed in more detail in this paper. In this section, these foods will be discussed with special reference to production methods, functional microbiota and their impact on the chemical composition and other quality traits, as well as the nutritional contribution that these products make to the diet.

\subsection{Maize products}

Maize has the largest kernels with a thousand kernel weight (TKW) of about $380 \mathrm{~g}$, and contains per $100 \mathrm{~g}$ grain, crude protein $9.4 \mathrm{~g}$, fat $4.2 \mathrm{~g}$, and carbohydrates $73.6 \mathrm{~g}$ of which fiber $1.9 \mathrm{~g}$. Because of its hardness and size, decortication by abrasion is feasible, and fine grinding is essential to obtain smooth texture of cooked products.

\subsubsection{Mawè}

Mawè is an uncooked fermented maize dough, which is made by washing, wet extraction of endosperm, kneading to a dough, followed by fermentation for about 3 days at ambient temperature (approx $30{ }^{\circ} \mathrm{C}$ ) (Hounhouigan et al., 1993a). Mawè serves as an important ingredient for the preparation of cooked beverages (koko), stiff gels (akassa, agidi, eko) and steamed cooked bread (ablo) in Bénin (Hounhouigan et al., 1993a). Although the fermentation is natural (uncontrolled), a certain "recycling" or backslopping of microorganisms takes place so that a rather consistent functional microbiota can be established. As shown in Table 2, heterofermentative lactic acid bacteria (Lactobacillus fermentum, $L b$. cellobiosus, Lb. brevis, Lb. curvatus, Lb. buchneri, Weissella confusa), pediococci and yeasts (Candida krusei, Candida kefyr, Candida glabrata, Saccharomyces cerevisiae) predominate in the fermented dough (Hounhouigan et al., 1994). The main functions of the fermentation include the formation of acidity, flavour, and enhancement of digestibility. Trials with added starter pure cultures of C. krusei and lactobacilli showed that the yeast had a stimulatory effect on the growth and acid production of $L b$. fermentum and $L b$. brevis (Hounhouigan et al., 1999). The flavour of defined mixed culture mawè was less pronounced as the traditional product. As a result of this fermentation, lactic and other organic acids lower the $\mathrm{pH}$ to about 3.5-4.0. From a nutritional point of view, mawè derived products such as agidi (Umoh and Fields, 1981) supply macronutrients, i.e. energy and some protein, as well as micronutrients, such as minerals and B vitamins. However, like in all cereals, the amino acid score of maize protein is low because of its relative deficiency in lysine (Henderickx and Vanneste, 1967). In the diet of average consumers, starchy staple foods are often eaten in combination with fish, or dishes made from cowpea (Vigna unguiculata) which can compensate for such lysine deficiencies.

\subsubsection{Kenkey}

Kenkey is a typical cooked bread-like maize product from Ghana. There are two types, namely Fanti- and Ga-kenkey which differ in salt content and packaging material (Muller and NyarkoMensah, 1972; Nout et al., 2007). To prepare kenkey, maize kernels are cleaned and then soaked in water for 2 days. The softened kernels are then ground entirely into whole meal semolina grits. Half of the mass is kneaded with some water into a dough that is allowed to ferment for 3-4 days, whereas the other half is mixed with water and cooked to obtain a gelatinized gluey mass called "aflata". Equal quantities of aflata and fermented dough are mixed and kneaded into a somewhat sticky dough which is moulded into balls (tennis ball size); these are wrapped in several layers of plant leaf and cooked in water for several hours. The final resulting kenkey has a shelf-life of several days, and is ready-to-eat, usually

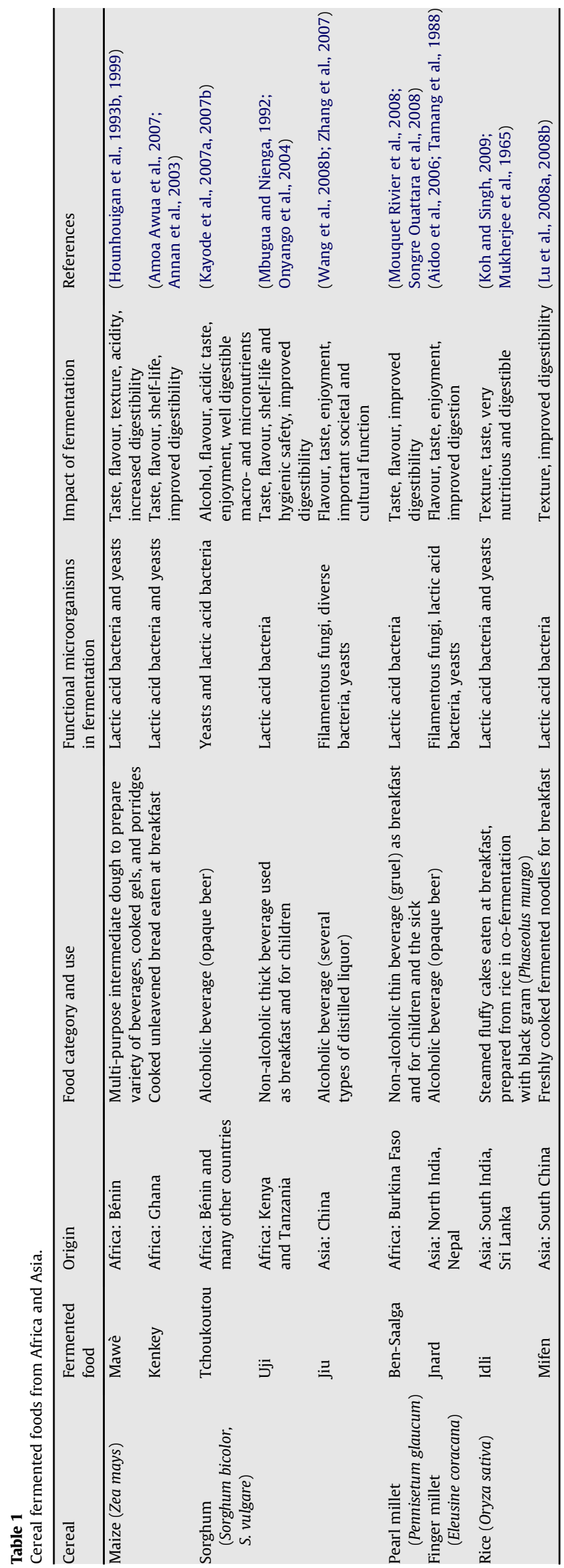


Table 2

Functional microbiota in cereal fermentations of tropical climates.

\begin{tabular}{|c|c|c|}
\hline Name & Foods & Function \\
\hline \multicolumn{3}{|l|}{ Bacteria } \\
\hline Acetic acid bacteria & daqu & Contribute to flavour by formation of acetate esters \\
\hline Bacillus spp. & daqu & Produce enzymes degrading starch, proteins, lipids, phosphates \\
\hline Enterococcus faecalis & amylolytic starters, idli, mifen & Contribute to flavour by mixed fermentation \\
\hline $\begin{array}{l}\text { Lactobacillus fermentum, Lb. cellobiosus, } \\
\text { Lb. brevis, Lb. curvatus, Lb. buchneri }\end{array}$ & mawè, kenkey, uji, ben-saalga, idli, mifen & Acidification, flavour formation, texture improvement \\
\hline Lactobacillus plantarum & uji, ben-saalga & Acidification, some strains degrade starch \\
\hline Leuconostoc mesenteroides & idli, mifen & Gas formation (leavening), flavour \\
\hline Pediococcus acidilactici, Pc. pentosaceus & mawè, uji, ben-saalga, amylolytic starters, mifen & Acidification \\
\hline Pc. dextrinicus & idli & Acidification \\
\hline Weissella confusa & mawè, ben-saalga & Acidification, flavour formation \\
\hline \multicolumn{3}{|l|}{ Yeasts } \\
\hline Candida krusei, C. kefyr, C. glabrata & mawè, kenkey, daqu & $\begin{array}{l}\text { Flavour formation, alcohols and esters, stimulation of lactic } \\
\text { acid bacteria, increased lysine availability }\end{array}$ \\
\hline Candida rugosa, Issatchenkia tropicalis & mifen & Starch modification, flavour \\
\hline Debaryomyces hansenii & idli & Flavour, stimulate LAB \\
\hline Endomycopsis fibuligera & amylolytic starters & Alcohol and flavour formation \\
\hline Hansenula spp. & daqu & Alcohol and flavour formation \\
\hline Pichia anomala & idli & Flavour, stimulate LAB \\
\hline Saccharomyces cerevisiae & $\begin{array}{l}\text { mawè, kenkey, tchoukoutou, daqu, amylolytic } \\
\text { starters, idli, mifen }\end{array}$ & Alcohol and ester formation, interaction with lactic acid bacteria \\
\hline Trichosporon pullulans & idli & Flavour, stimulate LAB \\
\hline \multicolumn{3}{|l|}{ Filamentous Fungi } \\
\hline Amylomyces rouxii & ragi, murcha, men and other amylolytic starters & Glucose release from starch by amyloglucosidase \\
\hline Aspergillus spp. & daqu & Amylolytic, proteolytic activity \\
\hline Mucor circinelloides, M. rouxii, M. indicus & ragi, murcha, daqu & Enzymic transformation, flavour production \\
\hline Rhizopus microsporus, $R$. oligosporus, $R$. oryzae & koji, daqu, murcha and other amylolytic starters & Texture, enzymic transformations, vitamins \\
\hline
\end{tabular}

with breakfast in combination with tea, sardines, chilli, etc. The unique aspect of this product is the use of aflata which functions as a "cement" to obtain a cohesive and mouldable dough, and which incorporates sufficient water to allow the uncooked maize to be fully cooked later (Nche et al., 1996). The fermentation of the maize dough resembles very much that of mawè as discussed above. The mild acidity in combination with cooking in tight packages allows for microbial stability and offers protection against dirt and dehydration, too. As shown in Table 2, dominant microorganisms are obligate heterofermentative lactobacilli, e.g., Lactobacillus fermentum, and yeasts, mainly C. krusei (Issatchenkia orientalis) and S. cerevisiae (Jespersen et al., 1994). During the kenkey production process, the level of available lysine increased from 1.3 in maize kernels to $3.3 \mathrm{~g}$ per $16 \mathrm{~g}$ nitrogen in ready-to-eat kenkey (Nche et al., 1995). In addition, flavour compounds (2,3-butanediol, butanoic acid, lactic acid, 3-methylbutanoic acid, octanoic acid, 2-phenylethanol, and propanoic acid) are formed during the fermentation stage (Jespersen et al., 1994).

\subsection{Sorghum products}

Sorghum grains (Hulse et al., 1980) have a medium size (TKW 23-45 g), and contain per $100 \mathrm{~g}$ grain, crude protein $9.8 \mathrm{~g}$, fat $3.1 \mathrm{~g}$, and carbohydrates $73.6 \mathrm{~g}$ of which fiber $2.3 \mathrm{~g}$. The grains are relatively soft and can be ground to fine flour easily. Decortication by abrasion is feasible, but will result in considerable breakage losses of about $15-20 \%$ of the original weight. At small scale, sorghum is pounded by pestle and mortar, after which the bran particles are removed by winnowing.

\subsubsection{Tchoukoutou}

Tchoukoutou is an "opaque beer" indicating its turbidity, caused by a lack of clarification. Many types of opaque beers (Novellie and De Schaepdrijver, 1986) are known in Africa and Asia, and tchoukoutou from Bénin serves as a representative in this paper. The beer is made from red sorghum by malting of red sorghum (soaking, germination and sun drying), brewing (mashing, boiling, filtration) and fermentation. The beer has a sour taste with a $\mathrm{pH}$ of 3.2, and contains a relatively high but variable level of solids and crude protein (Kayode et al., 2007b). The fermentation is predominated by yeasts (S. cerevisiae) and lactic acid bacteria. Local methods for the cultivation and preservation of beer starter organisms include the re-use of fresh biomass sedimented at the bottom of fermentation vessels, and of dehydrated starters on carriers of woven grass belts. During the fermentation, the wort sugars are transformed into ethanol, organic acids, $\mathrm{CO}_{2}$ and flavour compounds. Most opaque beers are consumed "fresh", after 1-3 days of fermentation. The longer fermented, the higher the alcohol content and the stronger the acid taste will be. Although one may argue that beer is not a food, opaque beers contain considerable amounts (4-13 g per $100 \mathrm{~g}$ beer) of grain dry matter and represent significant energy and protein with a high digestibility (Nout, 1987). It was shown that the solubility of iron in raw sorghum (3\% of total Fe) was increased to approx $20 \%$ of total Fe in tchoukoutou (Kayode et al., 2007a) which correlated with the decrease of the $\mathrm{pH}$ and the degradation of grain phytate.

\subsection{2. $U j i$}

$\mathrm{Uji}$ is a non-alcoholic cooked beverage which can be made from maize, sorghum or finger millet (Mbugua, 1985). Uji is very popular in East Africa where it is used as a convenient breakfast, and as a children's food. Not all uji is fermented: one can prepare fresh uji by boiling water and stirring in cereal flour to achieve the desired consistency. However, many consumers prefer fermented uji for its smoother texture, richer taste and ease of digestion. The antimicrobial effect of the acidity in fermented uji (Mbugua and Njenga, 1992) correlates with increased shelf-life and contributes to hygienic safety. The preparation of fermented uji (Onyango et al., 2004) involves soaking of the grains until soft, wet grinding by stone or machine, slurrying and removal of coarse particles and bran by filtration. The filtrate is allowed to ferment while the fine flour particles sediment. The supernatant (or some of it) is brought 
to the boil, and the wet sediment is gradually stirred into the boiling liquid to obtain a thin cooked beverage, to which often some sugar or salt is added for taste. The fermentation during sedimentation is predominated by lactic acid bacteria (Mbugua, 1985), i.e. Lactobacillus plantarum, Lb. fermentum, Lb. cellobiosus and $L b$. buchneri, Pediococcus acidilactici and Pc. pentosaceus. LAB are responsible for acid formation and concomitant $\mathrm{pH}$ decrease until $\sim 4$ (Mbugua and Njenga, 1992), and the formation of taste and flavour principles (Mbugua, 1991). From a nutritional point of view, traditional uji - having a dry matter content of $6-10 \mathrm{~g} / 100 \mathrm{ml}-$ is too diluted to be of any nutritional significance (Nout, 1993). For that reason, much effort has been made to develop similar beverages containing a much, i.e. 2-3 times, higher dry matter content, but which still have the original desirable spoonable viscosity. This can be achieved by using the inclusion of $\alpha$-amylase active germinated (malt) flour (Nout, 1993), or by using amylolytic lactic acid bacteria starters (Nguyen et al., 2007). Both approaches aim at liquefying the starch gel, as will be discussed later.

\subsubsection{Jiu}

Jiu is the generic Chinese word for "distilled liquor". There is a range of Jiu which have different flavours and corresponding names. Jiu has an alcoholic strength of about $40-45 \% \mathrm{v} / \mathrm{v}$. The consumption of jiu is part of Chinese culture, and it is almost essential during a meal with friends or at other festive occasions (Needham, 2000). Sorghum is the preferred cereal ingredient. Another important ingredient is "daqu", a fermented and drypreserved mixture of wheat, barley and peas, containing a complex mixed microbiota containing filamentous fungi (Rhizopus, Mucor, Aspergillus spp.) (Zhang et al., 2007), bacteria (acetic acid bacteria, lactic acid bacteria, bacilli) (Wang et al., 2008b) and yeasts (Saccharomyces, Candida, Hansenula spp.). Coarsely ground moistened whole-grain sorghum is cooked in a steam-cooker and allowed to cool. Pulverized daqu is added, and thoroughly mixed with the sorghum (Wang et al., 2008a). The warm mixture is transferred to jars which are sealed tightly and is left to ferment for about 1 month. Next, the fermented mass is transferred to a still and subjected to steam distillation. The distillate is collected and aged in ceramic jars for several months. Finally, the crude spirit is standardized to the desired alcohol content and bottled in glass bottles or ceramic jars. Obviously, it cannot be expected that such liquors supply a rich nutrition except that they contain energy. However, they may play a significant role in the digestion of the lunch or dinner by dissolving nutrients and by stimulating the digestive system.

\subsection{Millet products}

Millets have the smallest grains (Hulse et al., 1980). TKW of pearl millet is about $6 \mathrm{~g}$, and of finger millet only about $2.5 \mathrm{~g}$. Pearl millet contains per $100 \mathrm{~g}$ grain, crude protein $8.9 \mathrm{~g}$, fat $3.7 \mathrm{~g}$, and carbohydrates $74.9 \mathrm{~g}$ of which fiber $1.7 \mathrm{~g}$. Finger millet is higher in carbohydrates and contains per $100 \mathrm{~g}$ grain, crude protein $7.5 \mathrm{~g}$, fat $1.4 \mathrm{~g}$, and carbohydrates $76.5 \mathrm{~g}$ of which fiber $3.4 \mathrm{~g}$. Because of their small size, it is not feasible to decorticate the millet grains by abrasion. At small scale, millet grains are pounded by pestle and mortar, after which the bran particles are removed by winnowing.

\subsubsection{Ben-Saalga}

Ben-Saalga is a thin beverage or gruel obtained by cooking fermented sediment of pearl millet (P. glaucum) in water (Tou et al., 2006). It is a popular breakfast and children's beverage in Burkina Faso. The preparation process is carried out in the household and in small-scale home industries, and involves soaking of cleaned whole seeds of pearl millet in water overnight to aid grinding, wet milling with water to obtain a smooth slurry, sieving the slurry to remove coarse particles, allowing the filtrate to sediment and ferment simultaneously overnight and decanting the supernatant soak water. To prepare Ben-Saalga, a certain volume of decanted soak water is heated to boil, and carefully some sedimented mass is stirred in, to gelatinize its starch and to obtain a beverage of the desired thickness. Usually Ben-Saalga contains only 8-10 g/100 ml of dry matter (Tou et al., 2007), which makes it a poor source of energy and nutrients. The lactic acid bacteria in the natural fermentation include $L b$. fermentum, $L b$. plantarum and Pediococcus pentosaceus as majority organisms (Sifer et al., 2005). Some $L b$. plantarum strains were found to degrade starch (Ben Omar et al., 2006). During the process, considerable losses of millet nutrients take place as a result of discarding the coarse particles, and by leaching into the water fraction. On the positive side, antinutritional components of pearl millet, e.g., phytate was found to be degraded on average from 0.46 to $0.22 \mathrm{~g}$ per $100 \mathrm{~g}$ dry matter, i.e. by more than 50\% (Mouquet Rivier et al., 2008) in commercial BenSaalga. This reduction could facilitate the dietary uptake of proteins and minerals (Lestienne et al., 2005).

\subsubsection{Jnard}

Jnard (Tamang et al., 1988) is an opaque beer made from finger millet (E. coracana). Although - judging by its description - it would seem similar to Tchoukoutou, its mode of processing is fundamentally different. Whereas Tchoukoutou is brewed from sorghum malt, Jnard is saccharified by the action of an indigenous amylolytic starter (Murcha) (Hesseltine et al., 1988b; Tamang and Sarkar, 1995) on previously soaked and cooked fingermillet paste. Murcha is a rice-based dried tablet containing a mixed microflora of filamentous fungi, yeasts and lactic acid bacteria, and differs from koji which is a concentrate of fungal conidia of e.g. Aspergillus oryzae, used in the preparation of soya sauce and similar products (Nout and Aidoo., 2002). The process of preparing Jnard includes an overnight soak of finger millet seeds to soften them, grinding to obtain a crushed mass which is cooked and cooled to about $30^{\circ} \mathrm{C}$. Then, pulverized Murcha is sprinkled in the cooked mass and during a 1-3 day incubation, saccharification, lactic fermentation and alcoholic fermentation take place simultaneously. Functional microorganisms of Murcha and similar Asian amylolytic starters are filamentous fungi (Amylomyces rouxii, Rhizopus oryzae, etc.) which produce a range of enzymes including glucoamylase that degrades starch directly into glucose; yeasts (Endomycopsis fibuligera, S. cerevisiae, etc.) which ferment part of the glucose produced; and lactic acid bacteria (Enterococcus faecalis, P. pentosaceus and others) (Hesseltine and Ray, 1988a) growing together with the yeasts. LAB are able to co-exist with yeasts in a protocooperative manner (Nout, 1995). From a nutritional point of view, Jnard plays a similar role in India as Tchoukoutou in Bénin.

\subsection{Rice products}

Rice kernels are slightly smaller than sorghum; their TKW ranges from 16 to $27 \mathrm{~g}$ (Liang et al., 2008a). Rice contains per $100 \mathrm{~g}$ grain, crude protein $8.1 \mathrm{~g}$, fat $1.6 \mathrm{~g}$, and carbohydrates $76.6 \mathrm{~g}$ of which fiber $0.9 \mathrm{~g}$. After husking, brown (cargo) rice can be processed in different ways. Most rice is decorticated by abrasion "milling" to obtain white polished rice. Brown rice may also be parboiled, i.e., steamed or immersed in hot water followed by drying and milling as above. Parboiled rice retains more original minerals and vitamin B1 compared with polished white rice. A third option is not to decorticate, i.e. consume as brown rice. Parboiled rice and brown rice are generally not very appreciated because of their darker colour compared to white polished rice. 


\subsubsection{Idli}

Idli (Reddy et al., 1986) consists for $80 \%$ of rice (O. sativa). The remaining $20 \%$ is black gram (Phaseolus mungo), a leguminous seed. The mixture of white polished rice and black gram has a higher protein content and protein chemical score compared with rice only; black gram contains mucilaginous compounds which contribute to the texture of idli (Koh and Singh, 2009). To prepare idli, rice and black gram are processed separately. While rice is coarsely ground, the dal (dehulled split seeds of black gram) is ground into a smooth, mucilaginous paste. Rice and dal are then mixed in the required ratio and the resulting batter is left to ferment overnight at ambient temperature. After fermentation, the volume of the batter has increased 2-3 fold; this leavened batter is portioned into a cup-shaped steaming device and steamed into a fluffy and elastic cake. Idli cakes are eaten at breakfast in South India and Sri Lanka, in combination with coconut chutney and sambar (stew of tamarind and pigeon pea). The fermentation of idli is natural; no backslopping technique is used although the use of the same vessels and utensils may help to stabilize a mixed microflora of Leuconostoc mesenteroides, Lb. fermentum, Ent. faecalis, Pc. dextrinicus and yeasts especially Sacch. cerevisiae, Debaryomyces hansenii, Pichia anomala and Trichosporon pullulans. The function of these organisms is diverse. They contribute to the leavening of the batter and flavour formation. The lactic acid bacteria reduce the $\mathrm{pH}$ from 6 to about 4.2 which favours yeast growth. Yeasts contribute to starch degradation and gas formation, as well as to the accumulation of vitamin B and free amino acids (Nout et al., 2007).

\subsubsection{Mifen (Chinese rice noodles)}

Whereas the majority of rice consumption in China is in the form of cooked or steamed white polished rice, other rice-derived consumer products are popular in certain regions. In south China, freshly prepared rice noodles are customarily eaten at breakfast. These are produced in small- to medium-sized factories during the night and distributed fresh, early in the morning. The process of rice noodle making (Lu et al., 2005) includes soaking of rice kernels, grinding them to obtain a smooth slurry, pressing through a die, and cooking-gelatinization by dropping the freshly pressed strands of slurry into boiling water. The boiling is followed by rinsing the thus produced noodles in cold water to cool them and prevent their sticking together. During the soaking process ( $\sim 5$ days, $25^{\circ} \mathrm{C}$ ) a natural fermentation and acidification takes place in which Lactobacillus, Leuconostoc, Pediococcus, Streptococcus, Enterococcus and Aerococcus spp. and the yeasts S. cerevisiae, Candida rugosa, and Candida tropicalis were observed (Lu et al., 2005). The functionality of the mild acidification includes the protection against microbial spoilage, as well as the modification of the amorphous region of the starch granules which facilitates their gelatinization during cooking. Fermented noodles were reported to have better eating (chewing) qualities than non-fermented noodles (Lu et al., 2005). On the other hand, due to the character of the process, most water-soluble nutrients are lost and phytate is degraded, resulting in a product containing mainly starch and some protein. From a nutritional point of view, these noodles mainly provide energy. Traditionally, they are eaten as noodle soup which may contain vegetables and some meat or chicken depending on the budget. Given the endemic deficiencies of micronutrients such as iron and zinc, noodles - either rice noodles (south China) or wheat noodles (other regions) - may provide a suitable vehicle for fortification with Fe and $\mathrm{Zn}$.

\subsection{What can we learn from these processes?}

\subsubsection{Wet processing methods}

In tropical countries, wet processing of cereals is a tradition. Wet processing refers to soaking with or without fermentation or germination, and has certain advantages over dry processing. First, the softening of the protein matrix of the cereal grain allows for an improved extraction of starch by wet milling (Akingbala et al., 1987) and a smoother texture of resulting cooked beverages or porridges. Second, soaking activates endogenous enzymes such as amylases, proteases (Nche et al., 1996) and phosphatases (Zanabria Eyzaguirre et al., 2006) which facilitate the onset of fermentation through the generation of fermentable sugars (Nout, 1980) and amino acids. Phosphatase activity enhances the degradation of phytate with concomitant increase of digestibility (Liang et al., 2008b). During fermentation, lactic acid bacteria decrease the $\mathrm{pH}$ towards the optimum $\mathrm{pH}$ (about 5.5) of cereal phytase which enhances phytate degradation (Reale et al., 2007). When yeasts are present, there is also a likelihood of yeast phytase (Lambrechts et al., 1992) being produced. Soaking also activates germination, a process involving the activation of a range of enzymes including phytase. Germinated cereals such as rice were however, not observed to have strongly reduced phytate contents (Liang et al., 2008b).

\subsubsection{Multi-purpose intermediate products}

The concept of Mawè is a good example of an intermediate product. Whereas in most food processing companies, ready-to-eat items are produced, there may be excellent opportunities for diversification by selling intermediate products to consumers. One could imagine fresh sourdough in modified atmosphere packs, dehydrated fermented flour of different cereal mixes and extraction rates, etc. These could open novel culinary and technological applications, commercially and at home.

\subsubsection{Co-fermentation for texture and nutrition}

The example of idli illustrates the opportunities of co-fermentation of cereals and leguminous seeds. The combination of their proteins achieves higher chemical scores based on complementing amino acid profiles. The limiting amino acid in rice is lysine with a score of 62 compared to egg protein. Legumes such as mungbean have a lysine score of 120 and compensate the deficiencies of rice. Other cereals have even lower lysine scores, e.g. maize, sorghum and millet have scores of 49, 35 and 33 respectively (Young and Pellett, 1994). Moreover, the increase of the protein content is of technological interest as it may enhance gas retention (Romano et al., 2007) for dough leavening. Another example of co-fermentation is the addition of certain herbs and spices (Dung et al., 2005) in Asian fermented cereal products such as Vietnamese "Men" and Murcha, as well as in European fermented meat products (Verluyten et al., 2004). Some herbs contain significant levels of minerals. Manganese and other minerals in herbs are known to enhance the growth and acid formation of lactic acid bacteria (Raccach, 1985). This opens opportunities to stimulate or direct dominance in cereal lactic fermentations. On the other hand some spices such as garlic may have some antimicrobial effect that could be useful in the control of potential pathogens (Hew et al., 2006).

\subsubsection{Mixed culture fermentation}

Whereas S. cerevisiae is the world's best known industrial yeast, exotic fermentations often contain non-Saccharomyces yeast species, which may impart other flavours, and stimulate lactic acid bacteria. The microbial composition or profile of natural mixed cultures could be seen as an equilibrium condition influenced by a range of factors such as the chemical composition of the ingredients, the physicochemical changes brought about by the microflora, and specific growth rates and interactions between microbial species involved. This implies that in fermentations of the poor, the microbial profile of natural mixed cultures will show dynamic changes caused by variations in the use of ingredients, and of ambient incubation conditions. Systems such as backslopping 
(Nout and Rombouts, 1992) can help direct the composition of mixed cultures, as can the choice of substrate ingredients. More research is required to describe and model how microbial population dynamics respond to variations in substrate availability, metabolites accumulation and environmental conditions. Eventually this could contribute to better control of complex mixed starter cultures.

\subsection{How can the nutrition of the poor be enhanced?}

Three important factors that restrict the nutritional value of cereals are the swelling of the macronutrient starch upon cooking; limited protein content and quality; and low content and bioavailability of the micronutrients iron and zinc (Mouquet Rivier et al., 2008; Nout, 1993).

Cereal beverages of drinkable thickness are thus limited to 6-10 g dry matter per $100 \mathrm{ml}$ product because of their starch bulk. From a nutritional point of view this dry matter concentration supplies insufficient dietary nutrients and energy, i.e. the product is too much diluted. Ideally a 3-fold increase - up to $30 \mathrm{~g}$ dry matter per $100 \mathrm{ml}$ beverage - would be nutritionally adequate. Several investigators have demonstrated that with the use of $\alpha$-amylase-rich ingredients such as malted cereals (Malleshi and Desikachar, 1988), or of starch degrading lactic acid bacteria (Nguyen et al., 2007) for the fermentation, this goal can be achieved. Adequate nutrient and energy densities and a spoonable thickness can thus be combined.

In order to improve protein content and quality, the concept of co-fermentation of cereals and leguminous seeds can be extended to other products than idli. Several trials were done to upgrade the protein quality of kenkey by co-fermentation of maize and cowpea (Vigna unguiculata). Kenkey made with $80 \%$ maize and $20 \%$ white or red cowpea had higher protein contents, were more cohesive and were well accepted by Ghanaian consumers compared to whole maize kenkey (Nche et al., 1994). Co-fermentation of maize and cowpea was dominated by Lactobacillus plantarum and Lb. fermentum and the yeasts S. cerevisiae and I. orientalis (Sanni et al., 2002), and did not result in objectionable by-products (Nout et al., 1994).

Poor micronutrient iron and zinc supply is due to low Fe and $\mathrm{Zn}$ content, combined with low bioavailability of the minerals present (Allen et al., 2007). The latter limitation could be alleviated by wet processing options such as soaking and fermentation, as discussed before. The Fe and $\mathrm{Zn}$ content could be increased by adding suitable fortificants. According to WHO guidelines (Allen et al., 2007), appropriate fortificants for iron and zinc are NaFeEDTA and $\mathrm{ZnSO}_{4}$, respectively. Based on a daily consumption of 75-150 g wheat flour, a fortification level of $40 \mathrm{ppm}\left(40 \mathrm{mg} \mathrm{kg}-1\right.$, or $\left.0.11 \mathrm{mMol} \mathrm{kg}^{-1}\right)$ of NaFeEDTA was proposed recently (WHO, 2009). For these fortificants to be effective however, the phytate levels in the product should be as low as practicable (Hurrell et al., 2004); their effectiveness can be greatly enhanced in the presence of e.g. ascorbic acid (Davidsson et al., 1997). Zinc bioavailability is also increased in the presence of NaFeEDTA (Allen et al., 2007). Based on the BenSaalga process, we produced almost completely, and partly dephytinized pearl millet gruels containing 0.1 and $2.2 \mathrm{mMol}$ PA $\mathrm{kg}^{-1}$ dry matter, respectively. The partly dephytinized gruel had a PA level representative of commercial Ben-Saalga, cf. Mouquet Rivier et al. (2008). Fig. 1 shows the effect of the molar ratio of phytic acid concentration [PA] to total iron concentration [Fe] ([PA]/ $[\mathrm{Fe}]$ ), on the iron IVS (solubility after in-vitro enzymic digestion). The concentrations [PA] and [Fe] were varied by additions of phytic acid and NaFeEDTA, respectively. First, it should be noted that only at $[\mathrm{PA}] /[\mathrm{Fe}]$ ratio $\leq 0.3$, adequate IVS is achieved. Second, the IVS in "Ben-Saalga-like" partly dephytinized gruel (open squares $\square$ ) is less than $50 \%$. Finally, we consider the WHO guidelines of $40 \mathrm{ppm}$ fortification with NaFeEDTA, which corresponds with $0.11 \mathrm{mMol} \mathrm{kg}^{-1} \mathrm{Fe}$. In keeping with $[\mathrm{PA}] /[\mathrm{Fe}]$ ratio $\leq 0.3$, the

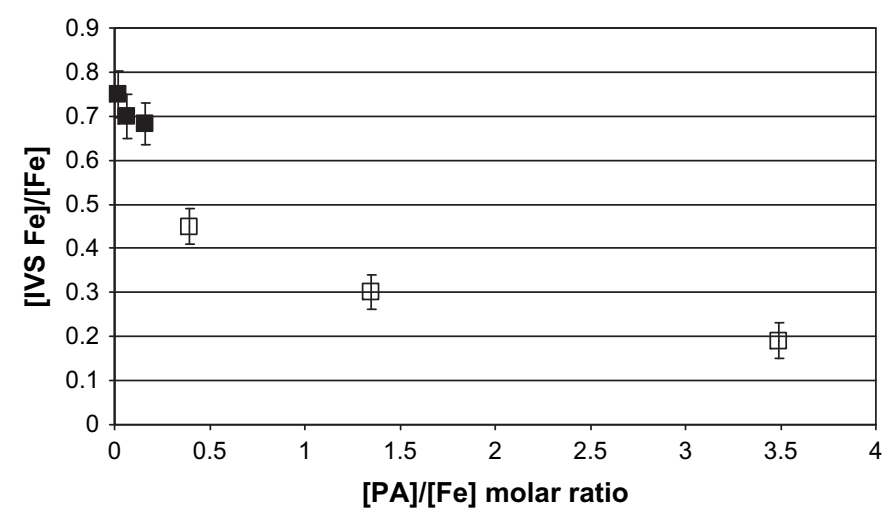

Fig. 1. Solubility of iron of NaFeEDTA as affected by Phytic acid:Fe molar ratios in matrices of fermented pearl millet gruel. $\mathbf{\square}$ : matrix of almost completely dephytinized pearl millet gruel ( $0.1 \mathrm{mM}$ phytic acid per kg dry matter); $\square$ : matrix of partly dephytinized pearl millet gruel (2.2 mM phytic acid per kg dry matter). [IVS Fe]/[Fe]: the fraction of total iron that is dissolved after in-vitro enzymic digestion; [PA]/[Fe molar ratio: moles of phytic acid present divided by moles of total Fe present. [PA] and [Fe] were adjusted by addition of the appropriate amounts of $\mathrm{Na}_{6}$ Phytate and NaFeEDTA to almost completely, and partly dephytinized pearl millet gruel. (Nout and Hasenack, 2008, unpublished data).

corresponding maximum PA level would be $0.033 \mathrm{mMol} \mathrm{kg}^{-1}$ (corresponding with $2 \mathrm{mg} 100 \mathrm{~g}^{-1}$ ) which is about $1 \%$ of PA levels observed in present commercial Ben-Saalga. In conclusion, the PA levels in this kind of cereal products need to be reduced to much lower levels. If the type of cereal or the process does not allow for adequate dephytinization, microbial phytases (Liang et al., 2009) have been shown to effectively degrade phytate.

With more technological effort to obtain acceptable, and dephytinized gruels, one would expect that these nutritional bottlenecks can eventually be overcome. However, other limiting factors of socio-economic nature may complicate or hamper such progress. One of the challenges for technologists is to integrate their efforts with those of other players and stakeholders in society and most importantly the population itself, so that sustainable solutions for a healthy nutrition will be achieved.

\section{Conclusion and perspectives}

It can be concluded that in tropical regions, mixed natural fermentations of cereals with lactic acid bacteria and yeasts ("sourdough fermentations") are widely practiced. These fermentations play an important role in providing wholesome food with attractive flavour and texture. From a nutrition point of view, new insights on increasing nutrient and energy density and on the removal of phytic acid, offer opportunities for future improvement of nutrient intake by consumers.

\section{Acknowledgement}

The technical collaboration of ing. Birgit Hasenack is greatly appreciated. Part of the data presented result from research funded by the European Commission (CEREFER project, contract No. ICA4CT-2002-10047).

\section{References}

Aidoo, K.E., Nout, M.J.R., Sarkar, P.K., 2006. Occurrence and function of yeasts in Asian indigenous fermented foods. FEMS Yeast Res. 6, 30-39.

Akingbala, J.O., Onochie, E.U., Adeyemi, I.A., Oguntimein, G.B., 1987. Steeping of whole and dry milled maize kernels in ogi preparation. J. Food Proc. Preserv. 11, $1-11$. 
Allen, L., de Benoist, B., Dary, O., Hurrell, R. (Eds.), 2007. Guidelines on Food Fortification with Micronutrients. WHO-FAO.

Amoa Awua, W.K., Ngunjiri, P., Anlobe, J., Kpodo, K., Halm, M., Hayford, A.E. Jakobsen, M., 2007. The effect of applying GMP and HACCP to traditional food processing at a semi-commercial kenkey production plant in Ghana. Food Contr. 18, 1449-1457.

Annan, N.T., Poll, L., Sefa Dedeh, S., Plahar, W.A., Jakobsen, M., 2003. Influence of starter culture combinations of Lactobacillus fermentum, Saccharomyces cerevisiae and Candida krusei on aroma in Ghanaian maize dough fermentation. Eur. Food Res. Technol. 216, 377-384.

Ben Omar, N., Abriouel, H., Lucas, R., Martinez Canamero, M., Guyot, J.P., Galvez, A., 2006. Isolation of bacteriocinogenic Lactobacillus plantarum strains from ben saalga, a traditional fermented gruel from Burkina Faso. Int. J. Food Microbiol. $112,44-50$

Davidsson, L., Galan, P., Cherouvrier, F., Kastenmayer, P., Juillerat, M.A., Hercberg, S., Hurrell, R.F., 1997. Bioavailability in infants of iron from infant cereals: effect of dephytinization. Am. J. Clin. Nutr. 65, 916-920.

Dung, N.T.P., Rombouts, F.M., Nout, M.J.R., 2005. Development of defined mixedculture fungal fermentation starter granulate for controlled production of rice wine. Innov. Food Sci. Emerg. Technol. 6, 429-441.

Henderickx, H.K., Vanneste, G., 1967. Maize-soybean mixtures as protein sources of high biological value. Z. Ernahr. Wiss. - J. Nutr. Sci. 8, 209-215.

Hesseltine, C.W., Ray, M.L., 1988a. Lactic acid bacteria in murcha and ragi. J. Appl. Bact. 64, 395-401.

Hesseltine, C.W., Rogers, R., Winarno, F.G., 1988b. Microbiological studies on amylolytic oriental fermentation starters. Mycopathol 101, 141-155.

Hew, C.M., Hajmeer, M.N., Farver, T.B., Riemann, H.P., Glover, J.M., Cliver, D.O., 2006 Pathogen survival in chorizos: ecological factors. J. Food Prot. 69, 1087-1095.

Hounhouigan, D.J., Nout, M.J.R., Nago, C.M., Houben, J.H., Rombouts, F.M., 1993a Changes in the physico-chemical properties of maize during natural fermentation of mawe. J. Cereal Sci. 17, 291-300.

Hounhouigan, D.J., Nout, M.J.R., Nago, C.M., Houben, J.H., Rombouts, F.M., 1993b. Composition and microbiological and physical attributes of mawé, a fermented maize dough from Bénin. Int. J. Food Technol. 28, 513-517.

Hounhouigan, D.J., Nout, M.J.R., Nago, C.M., Houben, J.H., Rombouts, F.M., 1994 Microbiological changes in mawe during natural fermentation. World J. Microbiol. Biotechnol. 10, 410-413.

Hounhouigan, D.J., Nout, M.J.R., Nago, C.M., Houben, J.H., Rombouts, F.M., 1999. Use of starter cultures of lactobacilli and yeast in the fermentation of mawe, an African maize product. Trop. Sci. 39, 220-226.

Hulse, J.H., Laing, E.M., Pearson, O.E., 1980. Sorghum and the Millets: Their Composition and Nutritive Value. Academic Press, London, United Kingdom.

Hurrell, R.F., Lynch, S., Bothwell, T., Cori, H., Glahn, R., Hertrampf, E., Kratky, Z. Miller, D., Rodenstein, M., Streekstra, H., Teucher, B., Turner, E., Yeung, C.K., Zimmermann, M.B., 2004. Enhancing the absorption of fortification iron a SUSTAIN task force report. Int. J. Vit. Nutr. Res. 74, 387-401.

Jespersen, L., Halm, M., Kpodo, K., Jakobsen, M., 1994. Significance of yeasts and moulds occurring in maize dough fermentation for "kenkey" production. Int. J. Food Microbiol. 24, 239-248.

Kayode, A.P.P., Hounhouigan, D.J., Nout, M.J.R., 2007a. Impact of brewing process operations on phytate, phenolic compounds and in-vitro solubility of iron and zinc in opaque sorghum beer. Food Sci. Technol. LWT 40, 834-841.

Kayode, A.P.P., Hounhouigan, D.J., Nout, M.J.R., Niehof, A., 2007b. Household production of sorghum beer in Benin: technological and socio-economical aspects. Int. J. Cons. Stud. 31, 258-264.

Koh, B.K., Singh, V., 2009. Cooking behavior of rice and black gram in the preparation of idli, a traditional fermented product of indian origin, by viscography. Jext. Stud. 40, 36-50.

Lambrechts, C., Boze, H., Moulin, G., Galzy, P., 1992. Utilization of phytate by some yeasts. Biot. Lett. 14, 61-66.

Lestienne, I., Besançon, P., Caporiccio, B., Lullien-Pellerin, V., Trèche, S., 2005. Iron and zinc in vitro availability in pearl millet flours (Pennisetum glaucum) with varying phytate, tannin, and fiber contents. J. Agric. Food Chem. 53, 3240-3247.

Liang, J., Han, B.-Z., Nout, M.J.R., Hamer, R.J., 2009. Effect of soaking and phytase treatment on phytic acid, calcium, iron and zinc in rice fractions. Food Chem. 115, 789-794.

Liang, J., Li, Z., Tsuji, K., Nakano, K., Nout, M.J.R., Hamer, R.J., 2008a. Milling characteristics and distribution of phytic acid and zinc in long-, medium- and shortgrain rice. J. Cereal Sci. 48, 83-91.

Liang, J.F., Han, B.Z., Nout, M.J.R., Hamer, R.J., 2008b. Effects of soaking, germination and fermentation on phytic acid, total and in vitro soluble zinc in brown rice. Food Chem. 110, 821-828.

Lu, Z.H., Cao, W., Peng, H.H., Wang, F., Tatsumi, E., Kohyama, K., Li, L.T., 2008a. Effect of fermentation metabolites on rheological and sensory properties of fermented rice noodles. J. Sci. Food Agric. 88, 2134-2141.

Lu, Z.H., Li, L.T., Min, W.H., Wang, F., Tatsumi, E., 2005. The effects of natura fermentation on the physical properties of rice flour and the rheological characteristics of rice noodles. Int. J. Food Sci. Technol. 40, 985-992.

Lu, Z.H., Peng, H.H., Cao, W., Tatsumi, E., Li, L.T., 2008b. Isolation, characterization and identification of lactic acid bacteria and yeasts from sour Mifen, a traditional fermented rice noodle from China. J. Appl. Microbiol. 105, 893-903.

Malleshi, N.G., Desikachar, H.S.R., 1988. Reducing the paste viscosity (dietary bulk) of roller dried weaning foods using malt flour or fungal amylase. J. Food Sci. Technol. 25, 1-3.
Mbugua, S.K., 1985. Isolation and characterization of lactic acid bacteria during the traditional fermentation of uji. East Afr. Agric. For. J. 50, 36-43.

Mbugua, S.K., 1991. A new approach to uji (an East African sour cereal porridge) processing and its nutritional implications. In: Prage, L. (Ed.), Development of Indigenous Fermented Foods and Food Technology in Africa. Proceedings from the IFS/UNU Workshop Held at Douala, Cameroon. IFS provisional report No.20, International Foundation for Science, Stockholm, Sweden, pp. 288-309. Oct 1985b.

Mbugua, S.K., Njenga, J., 1992. The antimicrobial activity of fermented uji. Ecol. Food Nutr. 28, 191-198.

Mouquet Rivier, C., Icard Vernière, C., Guyot, J.P., Hassane Tou, E., Rochette, I., Trèche, S., 2008. Consumption pattern, biochemical composition and nutritional value of fermented pearl millet gruels in Burkina Faso. Int. J. Food Sci. Nutr. 59, 716-729.

Mukherjee, S.K., Albury, M.N., Pederson, C.S., Van Veen, A.G., Steinkraus, K.H., 1965. Role of Leuconostoc mesenteroides in leavening the batter of idli, a fermented food of India. Appl. Microbiol. 13, 227-231.

Muller, H.G., Nyarko-Mensah, B., 1972. Studies on kenkey, a Ghanaian cereal food. J. Sci. Food Agric. 23, 544-545.

Nche, P.F., Nout, M.J.R., Rombouts, F.M., 1994. The effect of cowpea supplementation on the quality of kenkey, a traditional Ghanaian fermented maize food. J. Cereal Sci. 19, 191-197.

Nche, P.F., Nout, M.J.R., Rombouts, F.M., 1995. The effects of processing on the availability of lysine in kenkey, a Ghanaian fermented maize food. Int. J. Food Sci. Nutr. 46, 241-246.

Nche, P.F., Odamtten, G.T., Nout, M.J.R., Rombouts, F.M., 1996. Soaking of maize determines the quality of aflata for kenkey production. J Cereal Sci. 24, 291-297.

Needham, J., 2000. Biology and biological technology. In: Huang, H.T. (Ed.), Science and Civilization in China. Cambridge University Press, England, pp. 149-168.

Nguyen, T.T.T., Loiseau, G., Icard Vernière, C., Rochette, I., Trèche, S., Guyot, J.P., 2007. Effect of fermentation by amylolytic lactic acid bacteria, in process combinations, on characteristics of rice/soybean slurries: a new method for preparing high energy density complementary foods for young children. Food Chem. 100, 623-631.

Nout, M.J.R., 1980. Microbiological aspects of the traditional manufacture of Busaa, a Kenyan opaque maize beer. Chem. Mikrobiol. Technol. Lebensm. 6, 137-142.

Nout, M.J.R., 1987. Chemical composition and nutrient balance of Busaa, a Kenyan opaque maize beer. Chem. Mikrobiol. Technol. Lebensm. 11, 51-55.

Nout, M.J.R., 1993. Processed weaning foods for tropical climates. Int. J. Food Sci. Nutr. 43, 213-221.

Nout, M.J.R., 1995. Fungal interactions in food fermentations. Can. J. Bot. 73 (Suppl. 1), S1291-S1300.

Nout, M.J.R., Aidoo, K.E., 2002. Asian fungal fermented food. In: Osiewacz, H.D. (Ed.), The Mycota. Springer-Verlag, New York, N.Y, pp. 23-47.

Nout, M.J.R., Nche, P.F., Hollman, P.C.H., 1994. Investigation of the presence of biogenic amines and ethyl carbamate in kenkey made with maize and maizecowpea mixtures as influenced by process conditions. Food Addit. Contam. 11, 397-402.

Nout, M.J.R., Rombouts, F.M., 1992. Fermentative preservation of plant foods. J. Appl. Bact. 73, 136S-147S

Nout, M.J.R., Sarkar, P.K., Beuchat, L.R., 2007. Indigenous fermented foods. In: Doyle, M.P., Beuchat, L.R. (Eds.), Food Microbiology: Fundamentals and Frontiers. ASM Press, Washington, D.C, pp. 817-835.

Novellie, L., De Schaepdrijver, P., 1986. Modern developments in traditional African beers. Progr. Ind. Microbiol. 23, 73-157.

Onyango, C., Noetzold, H., Bley, T., Henle, T., 2004. Proximate composition and digestibility of fermented and extruded uji from maize-finger millet blend. Food Sci. Technol. LWT 37, 827-832.

Raccach, M., 1985. Manganese and lactic acid bacteria. J. Food Prot 48, 895-898.

Reale, A., Konietzny, U., Coppola, R., Sorrentino, E., Greiner, R., 2007. The importance of lactic acid bacteria for phytate degradation during cereal dough fermentation. J. Agric. Food Chem. 55, 2993-2997.

Reddy, N.R., Pierson, M.D., Salunkhe, D.K., 1986. Idli. In: Reddy, N.R., Pierson, M.D., Salunkhe, D.K. (Eds.), Legume-based Fermented Foods. CRC Press, Boca Raton, Florida, pp. 146-160.

Romano, A., Toraldo, G., Cavella, S., Masi, P., 2007. Description of leavening of bread dough with mathematical modelling. J. Food Eng. 83, 142-148.

Sanni, A.I., Sefa-Dedeh, S., Sakyi-Dawson, E., Asiedu, M., 2002. Microbiological evaluation of Ghanaian maize dough co-fermented with cowpea. Int. J. Food Sci. Nutr. 53, 367-373.

Sifer, M., Vernière, C., Galissaires, L., Castro, A., Lopez, G., Wacher, C., Guyot, J.P., 2005. DGGE community analysis of lactic acid fermented pearl millet-based infant gruels (ben-saalga, ben-kida) as a tool to characterize relatedness between traditional small-scale production units. In: 8th Symposium on Bacterial Genetics and Ecology, vol. 8, p. 1. Lyon.

Songre Ouattara, L.T., Mouquet Rivier, C., Icard Vernière, C., Humblot, C., Diawara, B., Guyot, J.P., 2008. Enzyme activities of lactic acid bacteria from a pearl millet fermented gruel (ben-saalga) of functional interest in nutrition. Int. J. Food Microbiol. 128, 395-400.

Tamang, J.P., Sarkar, P.K., 1995. Microflora of murcha: an amylolytic fermentation starter. Microbios 81, 115-122.

Tamang, J.P., Sarkar, P.K., Hesseltine, C.W., 1988. Traditional fermented foods and beverages of Darjeeling and Sikkim - a review. J. Sci. Food Agric. 44, 375-385.

Tou, E.H., Guyot, J.P., Mouquet Rivier, C., Rochette, I., Counil, E., Traore, A.S., Trèche, S., 2006. Study through surveys and fermentation kinetics of the 
traditional processing of pearl millet (Pennisetum glaucum) into Ben-Saalga, a fermented gruel from Burkina Faso. Int. J. Food Microbiol. 106, 52-60.

Tou, E.H., Mouquet Rivier, C., Rochette, I., Traore, A.S., Trèche, S., Guyot, J.P., 2007. Effect of different process combinations on the fermentation kinetics, microflora and energy density of Ben-Saalga, a fermented gruel from Burkina Faso. Food Chem. 100, 935-943.

Umoh, V., Fields, M., 1981. Fermentation of corn for Nigerian agidi. J. Food Sci. 46, 903-905.

Verluyten, J., Leroy, F., de Vuyst, L., 2004. Effects of different spices used in production of fermented sausages on growth of and curvacin a production by Lactobacillus curvatus LTH 1174. Appl. Environ. Microbiol. 70, 4807-4813.

Wang, C.-L., Shi, D.-J., Gong, G.-L., 2008a. Microorganisms in Daqu: a starter culture of Chinese Maotai-flavor liquor. World J. Microbiol. Biotechnol. 24, 2183-2190.
Wang, H.Y., Zhang, X.J., Zhao, L.P., Xu, Y., 2008b. Analysis and comparison of the bacterial community in fermented grains during the fermentation for two different styles of Chinese liquor. J. Ind. Microbiol. Biotechnol. 35, 603-609.

WHO, 2009. Recommendations on Wheat and Maize Flour Fortification Meeting Report: Interim Consensus Statement. World Health Organization, Geneva.

Young, V.R., Pellett, P.L., 1994. Plant proteins in relation to human protein and amino acid nutrition. Am. J. Clin. Nutr. 59, 1203S-1212S.

Zanabria Eyzaguirre, R., Nienaltowska, K., de Jong, L.E.Q., Hasenack, B.B.E. Nout, M.J.R., 2006. Effect of food processing of pearl millet (Pennisetum glaucum) IKMP-5 on the level of phenolics, phytate, iron and zinc. J. Sci. Food Agric. 86, 1391-1398.

Zhang, W.X., Qiao, Z.W., Tang, Y.Q., Hu, C., Sun, Q., Morimura, S., Kida, K., 2007. Analysis of the fungal community in zaopei during the production of Chinese luzhou-flavour liquor. J. Inst. Brew. 113, 21-27. 